\title{
Kompetensi Pustakawan di Era Industri 4.0 Dalam Menghadapi Information Overload
}

\author{
Mutty Hariyatia,, ${ }^{,}$, Heriyanto ${ }^{\mathrm{b}}$ \\ a UPT Perpustakaan, Universitas Negeri Surabaya, Surabaya, Indonesia \\ b Program Studi Ilmu Perpustakaan, FIB, Universitas Diponegoro, Semarang, Indonesia
}

Article Info

Received April 5, 2021

Revised April19, 2021

Accepted April 19, 2021

Keywords

- Information overload

- librarian competencies

- information society
Abstract

Introduction: The phenomenon of information overload experienced by the Indonesian people has caused many problems ranging from a decrease in the level of public awareness in understanding the validity and accuracy of information sources to changes in public information behavior. One of the problems in the flood of information is the increase of publications both scientific and popular which are the daily consumption of society which is very relevant to the librarian in the current situation and in the future.

Methodology: This research was conducted qualitatively by collecting data from literatures that relevant to the research theme. The collected data was then identified to find patterns that match the research objectives, namely to find out the competence of librarians that is relevant for the industrial era 4.0.

Discussion: The results show librarians need to have strategies in developing new ways to help people direct and focus their search for finding documents or information that are accurate and valid.

Conclusion: It is known that the information overload phenomenon is one of the hallmarks of this industrial 4.0 era so that it requires the development of librarian competencies in maintaining their contribution and existence in the information society.

\section{Pendahuluan}

Perkembangan peradaban manusia selalu mengalami perubahan dan telah mempengaruhi dunia di sekitar kita, termasuk mempengaruhi bagaimana seseorang saling berinteraksi dengan sesama. Interaksi antar pribadi ini juga dipengaruhi oleh perkembangan teknis dan teknologi produksi yang senantiasa berubah. Revolusi industri 4.0 merupakan isu terbaru di era industri saat ini, revolusi industri atau disebut era industri 4.0 tersebut telah menunjukkan bagaimana produksi industri mengikuti perkembangan dan perubahan terbaru dari waktu ke waktu. Dengan demikian, manusia, mesin, dan produksi itu sendiri merupakan kekuatan dalam satu jaringan yang cerdas dan independen (Vuksanović et al., 2016).

Seiring dengan revolusi industri 4.0, kita saat ini juga berada di era informasi, sebuah era di mana akses menuju sumber informasi dapat dilakukan dengan mudah bagi mayoritas masyarakat. Perkembangan dunia Internet menciptakan euporia terhadap kecepatan dan kemudahan dalam mengakses dan mendiseminasikan informasi. Teknologi informasi dan komunikasi membuat mudah untuk mentransfer informasi dan menyediakan sumber daya informasi pada setiap bidang. Teknologi berwujud e-mail, voice mail, telepon genggam, internet atau intranet cenderung disalahgunakan, daripada

\footnotetext{
${ }^{*}$ Corresponding author.

Email addresses: muttyhariyati@unesa.ac.id (M. Hariyati), heriyanto@live.undip.ac.id (Heriyanto)
} 
digunakan secara efektif dan produktif. Akibatnya teknologi dijadikan kambing hitam sebagai penyebab information overload. Fakta kemajuan teknologi telah membuat distribusi informasi menjadi lebih mudah, dan telah mengurangi proses seleksi alam yang seharusnya terjaga, sehingga hasilnya adalah ledakan yang sering tidak relevan dan iklim organisasi informasi yang berlebihan (Heylighen, 1999).

Peredaran informasi yang sangat cepat membuat hampir setiap orang berkontribusi dalam penciptaan informasi yang mejadikan laju pertumbuhan informasi bergerak dengan cepat pula. Informasi mudah untuk dicipta, ditemukan, dan selanjutnya dibagi, informasi juga bukan hanya melaju dari kuantitas namun juga kualitas. Hal ini dapat diartikan bahwa tidak semua informasi yang beredar merupakan informasi yang terjamin kebenarannya, diperlukan kecermatan dan keahlian dalam mengidentifikasi informasi dari sisi validitasnya. Setiap orang dari berbagai kalangan perlu memiliki pengetahuan dan kemampuan menilai keabsahan dan kebenaran informasi yang mereka peroleh. Setiap orang sebisa mungkin harus memiliki insting seorang pustakawan.

Perpustakaan dipandang sebagai tempat berbagai koleksi pengetahuan yang tersedia secara online dan tercetak untuk menyeimbangkan peran tradisionalnya (pendidikan dan pengajaran) sekaligus perpustakaan berkontribusi dalam menciptakan pengetahuanpengetahuan baru yang dihasilkan melalui penelitian (Oakleaf, 2016). Untuk dapat mempertahankan status perpustakaan sebagai pemain kunci dalam lanskap pengetahuan, maka perpustakaan harus menjaga kelebihan informasi agar tetap terlihat, Oleh karena itu, perpustakaan merupakan faktor kunci terhadap perubahan yang harus diadaptasi (Oakleaf, 2016).

Profesi pustakawan yang sering diidentikkan dengan koleksi buku tercetak mengalami banyak perkembangan seiring dengan perkembangan teknologi informasi dan komunikasi. Fenomena informasi yang terus berkembang, di antaranya information overload menjadikan profesi pustakawan juga mengalami evolusi. Peran pustakawan sebagai garda depan dalam mengelola informasi bertugas membantu pengguna mengatasi kelebihan informasi, mengidentifikasi sumber-sumber informasi yang bermanfaat dengan menggunakan alat bantu sehingga pengguna dapat bertahan atau bahkan menghindari informasi palsu (Oakleaf, 2016). Di tengah kondisi seperti ini, kompetensi pustakawan dituntut untuk mengalami perubahan seiring pula dengan perubahan perilaku pencari informasi. Dari latar belakang ini, maka kompetensi apa yang dibutuhkan pustakawan untuk menyikapi fenomena information overload?

\section{Tinjauan Pustaka}

\subsection{Industri 4.0}

Konsep dasar Industry 4.0 berasal dari negara Jerman yang merupakan pemimpin global di sektor peralatan manufaktur. Industry 4.0 merupakan inisiatif strategis dari pemerintah Jerman. Konsep ini dipresentasikan tahun 2011 pada pameran Hannover. Sejak saat itu industri 4.0 di Jerman menjadi topik diskusi dalam komunitas penelitian, akademisi dan industry di berbagai kesempatan (Rojko, 2017). Gagasan utama pertemuan tersebut memanfaatkan potensi teknologi dan konsep baru yang meliputi 4 komponen kunci yaitu, Internet of the Things, Cyber Physical Systems, Internet of Services dan Smart Factory (Lu, 2017; Hermann et al., 2015). Empat komponen tersebut menunjukkan meningkatkan kesadaran bahwa Industri 4.0 dan dimensinya bermanfaat untuk meningkatkan daya saing perusahaan. Memiliki peran penting pada tingkat kinerja perusahaan, efisiensi biaya, kualitas, dan meminimalisir bahkan meniadakan kesalahan. 
Hal ini berdampak pada kebutuhan pengembangkan kapasitas data dan statistik negaraznegara untuk bersiap-siap dalam perkembangan teknologi dan Industri 4.0 (Lu, 2017).

Industry 4.0 telah menjadi konsep yang sangat penting dalam beberapa tahun terakhir. Peningkatan penggunaan sistem digital dan komputerisasi, industry 4.0 menciptakan lebih banyak sistem digital dan integrasi jaringan melalui sistem pintar. Melalui Industry 4.0, sistem pintar akan memungkinkan penggantian manusia dalam tugas-tugas tertentu dan memudahkan pekerjaan lingkungan hidup (Erboz, 2017). Dengan bantuan Industry 4.0, industri akan memperoleh efisiensi operasional baik dalam waktu, biaya dan juga produktivitas.

Industry 4.0 adalah visi terkini yang membentuk masa depan kebanyakan industri dengan menciptakan model bisnis baru melalui Cyber Physical System(CPS). Oleh karena itu, sangat penting untuk menyelidiki dimensinya untuk mewujudkan efisiensi dalam lingkungan bisnis.

\subsection{Information Overload}

Kelebihan informasi bukan sebuah fenomena baru, potensi kelebihan muatan ada sejak informasi menjadi input penting bagi aktivitas manusia (Allen \& Wilson, 2003). Sejak tahun 1990-an, teknologi informasi dan komunikasi terutama internet telah mendorong produksi informasi menjadi lebih cepat, mudah dan relatif murah (Shachaf et al., 2016) sehingga pada sejumlah besar informasi yang dapat diakses melalui berbagai media berdampak meluap (Feather, 2008 dan Webster, 2009, dalam Shachaf et al., 2016). Peningkatan secara dramatis jumlah informasi formal dan informal dari masyarakat informasi menimbulkan kelebihan informasi dan telah menyebabkan masalah besar bagi masyarakat. (Seiger, 2003, dalam Jackson \& Farzaneh, 2012).

Meningkatnya dominasi media komputer sebagai media komunikasi, menunjukkan volume dan kecepatan informasi menjadi sangat luar biasa (Jackson \& Farzaneh, 2012). Definisi Information overload sebagai persepsi pribadi dari Allen \& Wilson (2003) menyebutkan bahwa arus informasi yang terkait tugas dengan beban berlebih daripada tugas yang dapat dikelola secara efektif dapat menimbulkan tingkat stres. Information overload di tingkat organisasi menciptakan situasi tingkat kelebihan informasi individu dalam organisasi yang cukup luas sehingga berdampak berkurangnya efektivitas operesional manajemen.

Informasi yang berlebihan menggambarkan situasi di mana kecepatan informasi mengalir sangat besar sehingga sulit untuk mengimbangi dan akses menuju kesana menjadi problem tersendiri. Kelebihan informasi juga menjadi masalah utama di negaranegara maju sehingga mengakibatkan kesenjangan antara volume informasi dengan alat untuk mengasimilasi informasi yang akan menghasilkan informasi bermanfaat (Umeozor, 2017). Jenis kelebihan yang dianggap serius adalah kepemilikan terhadap pengetahuan tentang keberadaan informasi yang dianggap relevan namun tidak dapat dipergunakan akibat kekurangan waktu (Wilson, 1997).

Umeozor (2017) berpendapat, bahwa kesenjangan kelebihan informasi membuat pustakawan dan ahli teknologi mencari cara untuk mengantisipasi dan mengembangkan alat bantu dalam mengendalikan ledakan informasi, sehingga kesenjangan kelebihan informasi dapat teratasi dan juga agar pengguna informasi mampu mengakses sumber daya yang tersedia.

\subsection{Kompetensi Pustakawan}

Kompetensi adalah inti dari sebuah profesi dan merupakan konsep sentral untuk memahami kualitas seorang profesional yang merupakan hubungan antara kematangan, 
kemampuan dan keberhasilan melaksanakan tugas dan pekerjaan (Huvila et al., 2013). Kompetensi dapat dilihat sebagai kombinasi dari pengetahuan praktis dan teoritis, keterampilan, perilaku dan nilai yang dibutuhkan untuk meningkatkan kinerja (Oyedokun et al., 2018). Untuk menguatkan hal tersebut, kompetensi merupakan kombinasi dari pengetahuan teoritis dan pengalaman praktis yang membentuk ciri khas keterampilan individu dalam mengambil tindakan yang tepat dalam mengerjakan tugas (Larzen, 2000, dalam Oyedokun et al., 2018).

Pustakawan merupakan sebuah profesi yang menekankan pada aspek kompetensi, di mana dalam mengemban tugas tersebut, pustakawan dituntut memiliki kompetensi secara profesional (Nashihuddin \& Aulianto, 2016). Titik Kismiyati dalam Hasbana, 2017) memaparkan bahwa seseorang yang memiliki motivasi keterampilan serta pengetahuan dan menjalankan tanggung jawab secara konsisten dalam memenuhi standar yang sudah ditetapkan merupakan standar kompetensi pustakawan.

Sebuah standar kompetensi sangat dibutuhkan sehubungan dengan pelaksanaan pekerjaan yang dilakukan pada instansi atau organisasi terkait sesuai dengan harapan pimpinan. Sehubungan dengan standar kompetensi, pemerintah melalui Keputusan Menteri Tenaga Kerja dan Transmigrasi no 83 tahun 2012 menetapkan Rancangan Standar Kompetensi Kerja Nasional Sektor Jasa Kemayarakatan, Sosial budaya Hiburan dan Perorangan lainnya bidang perpustakaan menjadi SKKNI. Berkaitan dengan kompetensi pustakawan dalam bidang perpustakaan, SKKNI membagi tiga unit kompetensi yang harus dimiliki oleh pustakawan.

\subsubsection{Kompetensi dasar/umum}

Kompetensi umum yaitu kompetensi dasar yang harus dimiliki oleh setiap pustakawan, diperlukan untuk melakukan tugas-tugas perpustakaan, meliputi: (1) mengoperasikan komputer tingkat dasar; (2) menyusun rencana kerja perpustakaan; (3) membuat laporan kerja perpustakaan. kompetensi umum ini melekat dalam kompetensi inti dan khusus.

\subsubsection{Kompetensi inti}

Kompetensi inti adalah kompetensi fungsional yang harus dimiliki oleh setiap pustakawan dalam menjalankan tugas-tugas perpustakaan. Kompetensi inti mencakup unit-unit kompetensi yang dibutuhkan untuk mengerjakan tugas-tugas inti dan wajib dikuasai oleh pustakawan. Kompetensi inti meliputi: (1) melakukan seleksi bahan perpustakaan; (2) melakukan pengadaan bahan perpustakaan; (3) melakukan pengatalogan deskriptif; (4) melakukan pengatalogan subyek; (5) melakukan perawatan bahan perpustakaan; (6) melakukan layanan sirkulasi; (7) melakukan layanan referensi; (8) melakukan penelusuran informasi sederhana; (9) melakukan promosi perpustakaan; (10) melakukan kegiatan literasi informasi; (11) memanfaatkan jaringan internet untuk layanan perpustakaan.

\subsubsection{Kompetensi khusus}

Kompetensi khusus merupakan kompetensi tingkat lanjut yang bersifat spesifik, meliputi: (1) merancang tata ruang dan perabot perpustakaan; (2) melakukan perbaikan bahan perpustakaan; (3) membuat literatur sekunder; (4) melakukan penelusuran informasi kompleks; (5) melakukan kajian perpustakaan; (6) membuat karya tulis ilmiah.

Deskripsi tentang kompetensi pustakawan juga disampaikan oleh The Special Libraries Association (SLA) atau Asosiasi Perpustakaan Khusus (SLA, 2016). Sejak tahun 2016 SLA 
telah memperbaharui dan meninjau kompetensi keterampilan dan pengetahuan yang dibutuhkan pustakawan. SLA yang merupakan organisasi internasional nirlaba untuk para profesional informasi inovatif dan mitra strategis telah merangkul para profesional informasi dari 60 negara dan di berbagai lingkungan kerja, termasuk bisnis, akademisi, dan lembaga pemerintah, termasuk di dalamnya inisiasi pembelajaran, advokasi, dan jaringan. SLA merekomendasikan kompetensi inti pustakawan di era informasi 4.0 sebagai berikut: (1) Layanan informasi dan pengetahuan, termasuk menganalisis arus informasi dan pengetahuan serta mengembangakan keterampilan literasi informasi di antara pemangku kepentingan; (2) Sistem dan teknologi informasi dan pengetahuan, yang mencakup perancangan interface untuk pengguna yang mencakup perancangan interface untuk kemudahan pengguna dalam penelusuran informasi; (3) Sumber daya informasi dan pengetahuan, termasuk menetapkan anggaran sumber daya dan menyelaraskan strategi untuk mengelola sumber daya informasi untuk memenuhi kebutuhan organisasi; (4) Temu kembali dan analisis informasi dan data, termasuk pengembangan strategi pencarian untuk temu kembali informasi dan menilai kualitas informasi; (5) Organisasi data, informasi dan asset pengetahuan, termasuk mengembangkan skema metadata dan taksonomi; dan (6) Etika informasi, yang meliputi model perilaku informasi etis dan mengenali permasalahan etika yang berhubungan dengan penanganan informasi

\section{Metode}

Penelitian ini dilakukan dengan meninjau pustaka untuk mengeksplorasi hasil-hasil penelitian yang terkait dengan topik yang dikaji. Literatur yang dikumpulkan adalah sumber-sumber informasi berupa artikel ilmiah, laporan penelitian dan beberapa buku yang membahas tentang fenomena information overload dan kompetensi pustakawan. Melalui berbagai sumber informasi yang telah dikumpulkan tersebut, maka jawaban atas pertanyaan bagaimana pustakawan menyikapi fenomena information overload dan kompetensi apa yang perlu dimiliki pustakawan di tengah kondisi meluapnya informasi dan sumber informasi dapat terjawabkan.

\section{Pembahasan}

Pustakawan sebagai pemangku kepentingan informasi adalah sebuah profesi yang memiliki pengetahuan dan keterampilan yang memungkinkan pustakawan mengetahui cara menemukan, mengakses, mengevaluasi dan menggunakan informasi secara efektif dan sesuai dengan kebutuhan, baik kebutuhan dalam mendukung profesinya maupun memenuhi kebutuhan informasi masyarakat yang dilayaninya (Anunobi \& Udem, 2014). Seorang pustakawan memiliki kompetensi yang unggul sehingga mampu menghadapi informasi yang berlimpah di era Industri 4.0 yang juga dikenal sebagai era intelijensi informasi. Oleh karena itu, sebuah standar kompetensi yang menuliskan kompetensi pustakawan dibutuhkan terkait dengan pelaksanaan pekerjaan yang dilakukan pada instansi atau organisasi terkait sesuai dengan harapan para stakeholders dilingkungan pustakawan.

Fenomena information overload yang dialami oleh sebagian besar masyarakat di Indonesia menjadikan peluang sekaligus tantangan bagi pustakawan untuk menunjukkan kontribusi sekaligus eksistensi seorang ahli informasi ditengah laju informasi yang cepat. Pustakawan bukan hanya harus bisa memahami kebutuhan dan perilaku informasi masyarakat yang dilayani, namun juga membantu diri mereka sendiri untuk tetap survive ditengah popularitas Google yang sudah banyak dikenal dan digunakan masyarakat. 
Perubahan perilaku pencarian informasi masyarakat harus sudah bisa diidentifikasi oleh para pustakawan dinegeri ini dan berlanjut menciptakan inovasi-inovasi kompetensi baru yang harus dikuasai profesi ini.

Pustakawan tidak boleh larut dalam banjir informasi. Pustakawan adalah seorang lifesaver atau yang menyelamatkan orang yang terancam tenggelam dalam gelombang keras laju informasi. Profesi ini harus menjadi lebih mahir di masa depan dalam mengembangkan cara untuk membantu pengguna dalam mempersempit atau memfokuskan pencarian informasi mereka ke dokumen yang paling penting atau kunci dalam bidang studi. Sejumlah upaya yang telah dilakukan di perpustakaan dan profesi informasi untuk membantu pengguna mengatasi kelebihan informasi diperiksa serta spekulasi tentang beberapa cara masa depan dalam menangani masalah tersebut pernah direkomendasikan oleh Hopkins (1995).

Ada beberapa cara yang dapat dilakukan oleh pustakawan dalam menghadapi Information overload (Hopkins, 1995).

\subsection{Membuat buku panduan dan artikel tinjauan.}

Menyediakan panduan cetak, buku pegangan, dan artikel ulasan canggih. Jenis sumber ini efektif dalam membantu pengguna untuk membuat penilaian yang berkualitas tentang relevansi dokumen tertentu untuk kebutuhan informasi tertentu. mencakup literatur sekunder dari bidang tersebut; mereka selektif di alam; dan mereka disusun dalam format naratif. Jenis-jenis sumber yang dimaksudkan di sini adalah panduan naratif untuk literatur subjek, buku pegangan ilmiah, dan artikel ulasan mutakhir.

\subsection{Pendekatan elektronik untuk mencari informasi.}

Pustakawan sangat menyadari bahwa ada banyak kemampuan pencarian yang dimungkinkan dengan sumber elektronik yang sama sekali tidak tersedia dengan sumber cetak atau manual, misalnya penggunaan "boolean logic", advance search, dan filter untuk membatasi pencarian informasi sehingga informasi yang dihasilkan akan lebih akurat.

\subsection{Melakukan "penambahan kemampuan hypertext ke sistem informasi perpustakaan".}

Salah satu aplikasi hypertext ini, adalah untuk memungkinkan pengguna secara langsung memasukkan komentar evaluatif pribadi mereka ke dalam sistem mengenai kualitas atau kegunaan berbagai dokumen, contohnya menambahkan informasi-informasi yang berkaitan dengan sumber utama di dalam sistem informasi perpustakaan seperti subjek atau penulis atau keterangan-keterangan lain seperti abstrak dan resensi buku.

\subsection{Mengadakan Pendidikan Pemakai.}

Pada pelatihan pengguna untuk lebih selektif, membuat penilaian yang lebih berkualitas sendiri, tentang informasi yang mereka ambil. Ini tentu saja merupakan salah satu tujuan utama gerakan literasi informasi. Orang yang melek informasi telah ditentang sebagai satu: yang mampu mengenali kapan informasi dibutuhkan dan memiliki kemampuan untuk menemukan, mengevaluasi, dan menggunakannya secara efektif (Heriyanto, 2020). Orang yang melek informasi telah belajar cara belajar dan siap untuk belajar seumur hidup.

Hashim dan Mokhtar (2012), dalam Kurniasih (2015) mengelompokkan kemampuan pustakawan dalam dua kategori yaitu professional ability dan personal ability. (1) Professional ability adalah kemampuan untuk menyaring dan mengevaluasi kelayakan 
informasi, kemampuan menyebarkan dan mengorganisasikan informasi, kemampuan melakukan penilaian dan evaluasi luaran penggunaan informasi, kemampuan meningkatkan layanan pengguna dan kemampuan dalam desain layanan teknologi informasi, serta kemampuan meningkatkan biaya layanan informasi secara efektif. (2) Personal ability adalah kemampuan bersikap fleksibel, kemampuan berkomunikasi secara efektif, berperilaku positif, kemampuan bekerjasama dan memimpin, kemampuan mencari peluang untuk pembelajaran sepanjang hayat berkaitan dengan lingkungan layanan pengguna dan seperangkat keterampilan yang merujuk kepada kelangsungan hidup.

Pendukung utama pengembangan perpustakaan digital, Tennant (2000) dalam Marion (2001), mengemukakan bahwa pustakawan harus memiliki ketrampilan dalam mengelola dan menciptakan koleksi dan layanan digital meliputi: teknologi pencitraan, pengenalan karakter optic (OCR), katalog dan metadata, bahasa pemrograman (HTML, SGML, XML), teknologi pengindeksan dan database, desain antarmuka pengguna, pemrograman, teknologi web dan manajemen proyek.

Selain keterampilan di atas, Tennant (2000), dalam Marion (2001) mengantisipasi bahwa laju teknologi dapat usang dalam waktu singkat. Untuk mengantisipasi hal tersebut, pustakawan harus mempunyai kemampuan atau sifat pribadi seperti kapasitas untuk belajar secara konstan dan cepat, fleksibel, skeptisme bawaan, berani mengambil resiko, mematuhi perspektif layanan publik, keterampilan interpersonal yang baik, ketrampilan mengaktifkan dan mendorong perubahan dan bekerja secara mandiri (Marion, 2001).

International Federation of Library Assosiation (IFLA) sejak tahun 2002 memberikan wadah yang benama Continuing Professional Development and Workplace Learning Section (CPDWL) yang dipimpin oleh Gillian Hallam (Smith, 2004). Program ini ditujukan kepada pustakawan yang tertarik dan bertanggung jawab meningkatkan kualitas sistem untuk memberikan pengembangan profesional berkelanjutan dan program pembelajaran di tempat kerja. Dengan mengikuti program tersebut, akan membantu kegiatan praktis dan kegiatan yang terkait dengan penelitian dalam bidang keahlian subjek yang ditawarkan. Semua aspek pengembangan profesional dan pembelajaran di tempat kerja dalam periode pasca-kualifikasi hingga akhir karier.

\section{Simpulan}

Studi tentang kompetensi pustakawan di era industri dan di tengah peristiwa banjir informasi sudah dilakukan oleh beberapa peneliti. Fakta ini menggambarkan bahwa kebutuhan untuk meningkatkan kompetensi pustakawan dalam menjaga kontribusi dan eksistensi pustakawan di tengah masyarakat informasi adalah hal yang sangat penting dilakukan. Profesi pustakawan merupakan profesi yang tidak statis, profesi ini dinamis mengikuti perubahan jaman dan perubahan perilaku informasi masyarakat. Pustakawan harus tetap mengusung nilai professional ability dan personal ability untuk menyelamatkan masyarakat dan juga diri profesi ini sendiri supaya tidak ikut tenggelam dari luapan banjir informasi. Pustakawan adalah sebuah profesi yang bukan hanya mampu survive dalam luapan samudra informasi, namun juga profesi yang kompeten dalam mengidentifikasi kemunculan berbagai macam sumber informasi dan mengantisipasi dinamika perilaku informasi masyarakat. 
Daftar Pustaka

Allen, D., \& Wilson, T. D. (2003). Information overload: context and causes. The New Review of Information Behaviour Research, 4(1), 31-44. https://doi.org/10.1080/14716310310001631426

Anunobi, C. V., \& Udem, O. K. (2014). Information Literacy Competencies: A Conceptual Analysis. Journal of Applied Information Science and Technology, 72). https://doi.org/10.31229/osf.io/bsza6

Erboz, G. (2017). How To Define Industry 4.0: Main Pillars Of Industry 4.0. In I. Košičiarová \& Z. Kádeková (Ed.), International scientifis conference Managerial trends in the development of enterprises in globalization era (hal. 761-767). Faculty of Economics and Management, Slovak University of Agriculture in Nitra. https://www.researchgate.net/publication/326557388_How_To_Define_Industry_4 0_Main_Pillars_Of_Industry_40

Hasbana, A. (2017). Standar kompetensi pustakawan sebagai instrumen asesmen jabatan fungsional pustakawan. $A L-M A K T A B A H, 16(1)$. http://journal.uinjkt.ac.id/index.php/al-maktabah/article/view/8090

Heriyanto, H. (2020). Preferensi penggunaan sumber informasi oleh mahasiswa dalam menyelesaikan tugas kuliah. Jurnal Kajian Informasi \& Perpustakaan, 8(1), 35-48. https://doi.org/10.24198/jkip.v8i1.23440

Hermann, M., Pentek, T., \& Otto, B. (2015). Design Principles for Industrie 4.0 Scenarios: A Literature Review. In Technische Universitat Dortmund(No. 01). https://www.researchgate.net/profile/Mario-Hermann2/publication/307864150_Design_Principles_for_Industrie_40_Scenarios_A_Literatu re_Review/links/57cfd2fb08aed6789701cbeb/Design-Principles-for-Industrie-40Scenarios-A-Literature-Review.pdf

Heylighen, F. (1999, Februari 19). Change and Information Overload: negative effects. http://pespmc1.vub.ac.be/CHINNEG.html

Hopkins, R. L. (1995). Countering information overload: The role of the librarian. Reference Librarian, 23(49-50), 305-333. https://doi.org/10.1080/J120v23n49_21

Huvila, I., Holmberg, K., Kronqvist-Berg, M., Nivakoski, O., \& Widén, G. (2013). What is Librarian 2.0 - New competencies or interactive relations? A library professional viewpoint. Journal of Librarianship and Information Science, 45(3), 198-205. https://doi.org/10.1177/0961000613477122

Jackson, T. W., \& Farzaneh, P. (2012). Theory-based model of factors affecting information overload. International Journal of Information Management, 32(6), 523-532. https://doi.org/10.1016/j.ijinfomgt.2012.04.006

Kurniasih, N. (2015). Kualifikasi Pustakawan di Era Digital. In Sulistyo Basuki, Laksmi, Laksmi Dewi, Riche Cynthia, \& Pawit M. Yusuf(Ed.), Semiloka Nasional Kepustakawanan Indonesia "Library Move on: Bangga Menjadi Profesional di Dunia Perpustakaan dan Informasi” (hal. 439-449). Ikatan Sarjana Ilmu Perpustakaan dan Informasi Indonesia. https://www.researchgate.net/publication/308508161_Kualifikasi_Pustakawan_di_ Era_Digital

Lu, Y. (2017). Industry 4.0: A survey on technologies, applications and open research issues. Journal of Industrial Information Integration, 6, 1-10. https://doi.org/https://doi.org/10.1016/j.jii.2017.04.005

Marion, L. (2001). Digital librarian, cybrarian, or librarian with specialized skills: Who will staff digital libraries. ACRL Tenth National Conference, 143-149. https://news.ala.org/ala/acrl/acrlevents/marion.pdf

Nashihuddin, W., \& Aulianto, D. R. (2016). Strategi peningkatan kompetensi dan 
profesionalisme pustakawan di perpustakaan khusus. Jurnal Perpustakaan Pertanian, 24(2), 51. https://doi.org/10.21082/jpp.v24n2.2015.p51-58

Oakleaf, M. (2016). Getting Ready \& Getting Started: Academic Librarian Involvement in Institutional Learning Analytics Initiatives. Journal of Academic Librarianship, 42(4), 472-475. https://doi.org/10.1016/j.acalib.2016.05.013

Oyedokun, T. T., Oyewumi, F. A., Akanbi, M. L., \& Laaro, D. M. (2018). Assesment of ICT competencies of Library Staff in Selected Universities in Kwara State, Nigeria. Library Philosophy and Practice (e-journal). https://digitalcommons.unl.edu/libphilprac/1797

Rojko, A. (2017). Industry 4.0 Concept: Background and Overview. International Journal of Interactive Mobile Technologies (iJIM), 11(5), 77-90. https://doi.org/10.3991/ijim.v11i5.7072

Shachaf, O., Aharony, N., \& Baruchson, S. (2016). The effects of information overload on reference librarians. Library and Information Science Research, 38(4), 301-307. https://doi.org/10.1016/j.lisr.2016.11.005

Smith, I. W. (2004). Continuing professional development and workplace learning 6: HRD and organisational learning. Library Management, 25(1450), 64-66. https://doi.org/10.1108/01435120410510274

Special Libraries Association. (2016, April 13). Competencies for Information Professionals. https://www.sla.org/about-sla/competencies/

Umeozor, S. N. (2017). Information and Knowledge Management Information Overload: A Case for the Developing Countries. Information and Knowledge Management, 712), 35-39. www.iiste.org

Vuksanović, D., Ugarak, J., \& Korčok, D. (2016). Industry 4.0: the Future Concepts and New Visions of Factory of the Future Development. 293-298. https://doi.org/10.15308/sinteza-2016-293-298

Wilson, T. . (1997). Information behaviour: an interdisciplinary approach. Information Processing and Management, 33(4), 551-572. 